\title{
Consumerism in Personal Finance: An Islamic Wealth Management Approach
}

\author{
Farisah Amanda ${ }^{1}$, Bayu Taufiq Possumah ${ }^{2}$, Achmad Firdaus ${ }^{3}$
}

\begin{abstract}
The aims of this study are to understand the causes and impacts of consumerism on personal finance and find the solution to this problem by using Islamic wealth management. By using thematic analysis this study reviewing consumerism from the perspective of personal finance in Islamic wealth management approach. This study found that the causes of consumerism involve both external and internal factors. The impacts of consumerism on personal finance are the debt trap, no productive and charity allocation. An exact number of maximum consumption cannot be set for every individual or family, but they are all agreed that allocating income should be based on the right priority scale. The second finding is we propose Islamic Wealth Management (IWM) approaches in reducing the problem of Consumerism.
\end{abstract}

Keywords: consumerism, personal finance, financial planning, Islamic wealth management

\begin{abstract}
Abstrak. Tujuan dari penelitian ini adalah untuk mengetahui penyebab dan dampak konsumerisme terhadap keuangan pribadi dan menemukan solusi untuk masalah ini dengan menggunakan pendekatan pengelolaan kekayaan Islam. Dengan menggunakan analisis tematik studi ini mengkaji konsumerisme dari perspektifkeuangan pribadi dalam pendekatan pengelolaan kekayaan Islam. Studi ini menemukan bahwa penyebab konsumerisme melibatkan faktor eksternal dan internal. Dampak konsumerisme terhadap keuangan pribadi adalah: perangkap hutang, tidak ada alokasi produktif dan amal. Jumlah konsumsi maksimum pasti tidak dapat ditetapkan untuk setiap individu atau keluarga, namun mereka semua sepakat bahwa mengalokasikan pendapatan harus didasarkan pada skala prioritas yang tepat. Temuan kedua adalah kami mengusulkan pendekatan Islamic Wealth Management (IWM) dalam mengurangi masalah Konsumerisme.
\end{abstract}

Kata Kunci: konsumerisme, keuangan pribadi, perencanaan keuangan, manajemen kekayaan Islam

\section{How to Cite:}

Amanda, F., Possumah, B. T., \& Firdaus, A. (2018). Consumerism in Personal Finance: An Islamic Wealth Management Approach. Al-Iqtishad:Jurnal Ilmu Ekonomi Syariah (Journal of Islamic Economics). Vol. 10 (2): 325 - 340. doi: http://dx.doi.org/10.15408/aiq.v10i2.5518. 


\section{Introduction}

The financial industry in the modern world has developed and created a vast amount of sophisticated products. It provides people with various kinds of financial products, while not every product suitable for everyone. This is rising the most fundamental process that generates consumerism is the nature of profit-maximizing competition in a capitalist economy. One of the great virtues of capitalism is that the competition among firms puts pressures on firms to innovate, and many of these innovations increase productivity over time to satiate the consumers.

Alongside, the emergence and development of consumer culture have widespread throughout the world. Consumerism as the main value of consumer culture has become an international phenomenon (Stearns, 2001). Industrial era with globalization and capitalism helped promote consumerism as a part of the modern world (Kasser and Kanner, 2004). Despite the advantages, consumerism also brings numerous perceived problems to the society. Among the issues are mentioned here as: first, the shift of value away from traditional kinship and religious values into the value of consumerism (Heryanto, 2004). second, inequality in income, wealth, and power (Dowd, 2009); and, third, a new kind of poverty of flawed consumer (Bauman, 2005).

The term consumerism used in this study is defined as excessive materialism and a waste of resources (Swagler, 2005). In individual level, negative feeling towards oneself causes consumerism; and as a result, psychological well-being cannot be achieved (Kasser, 2004). In personal finance perspective, financial literacy can be used to counterbalance consumerism and to put it into perspective in managing personal finance. It is very unfortunate that there is no sufficient amount of personal finance education to help boost financial literacy available in the system. In another hand, Islam as a comprehensive religion should be able to provide a solution for every problem in human life, including the problem of consumerism. This is also in accordance to the fact that in Islam, the concept of economic development is comprehensive and integrated between aspects of moral, spiritual, material, social, and economic (Possumah et al., 2012). Hence, since the studies on consumerism are rarely touched by religious aspect, the contribution of this study is bringing the issues of consumerism into financial management issues especially on how literately Muslim Consumers in their behavior.

\section{Literature Review}

\section{Consumerism and Consumer Behavior Study}

Consumer behavior is interdisciplinary and is based on concepts and theories developed by scientists, philosophers and researchers in diverse disciplines as well as 
have become an integral part of the economics discipline. In the field of Economics consumer behavior defined as the study of the processes involved when individuals or groups select, purchase, use or dispose of products, services, ideas or experiences to satisfy needs and desires (Solomon, 2013). There are five stated individual determinants of consumer behavior: motivation and involvement, personality and self-concept, perception and information processing, learning and memory, attitude formation and change. While external influences on consumer behavior consist of reference group and family, social class, culture, subculture (Taylor and Overbey, 1999; Wrenn, 2013).

The external and internal factors mentioned are involved in a consumer decision-making process (Essoussi and Linton, 2010). One of the factors is motivation, which refers to the processes that cause people to behave as they do. Motivation occurs when a need is aroused that the consumer wishes to satisfy, and a need can be utilitarian, or it may be hedonic (O'Neill et al., 2000). A utilitarian need is a desire to achieve some functional or practical benefit, while a hedonic need is an experiential need, involving emotional responses or fantasies. A want is a manifestation of a need, which is the particular form of consumption used to satisfy a need, it is influenced by factors such as cultural, religious, ethnic, or national background (Solomon, 2013). Maslow's hierarchy of needs implicates that one must first satisfy basic needs before progressing up the ladder of needs. The hierarchy starts with lower-level needs to upper-level needs: physiological, safety, belongingness, ego needs, and self-actualization.

Materialism, which refers to the importance people attach to worldly possession, may be considered a more general value underlying other consumer values, reassuring that an obvious way of realizing one's values is through consumption (Solomon, 2013). These statements of consumer behavior are all based on the study of the western society mainly Europe and America. The problem arises when widely accepted theories of social change have limited applicability for critical analysis of the consumerism (see Basgöze and Tektas, 2012). Since the 1980s a rich body of theories of social change has emerged in the fields of social movement studies, organizational theory, economic sociology, historical institutionalism in political science, as well as the most recent effort to develop a unifying synthesis of those (Fligstein and McAdam, 2012 cited in Halina and Vergragt, 2015). Hence this study attempt to elaborate the issue in rarely touched approach, because we believe that the belief, ethics and social responsibility should also be integral components of every consumption decision is embodied in a revised wealth or financial planning concept. 


\section{Personal Financial Planning in the Eye of Islamic Wealth Management (IWM)}

Wealth management, in general, is defined as the process of managing assets of individual or family that has used, and the value can increase or decrease over time (Manurung, 2008). While wealth management as a study is defined as a study of how to protect and save wealth, how to generate and accumulate wealth, and how to pass wealth and facing transition and retirement (Indrajit, 2011). Islamic wealth management consists of Islamic financial planning and investment portfolio management. Financial planning is a discipline of wealth management that applies to the unique needs and concerns of each respectively. The components of Islamic financial planning should include, but not limited to these areas: wealth generation, wealth protection, wealth accumulation, wealth purification, and wealth distribution as shows in Figure 1 (Shafii et al., 2013).

If we review some literature by scholars, we can shortlist significant elements of Islamic management of wealth categorized are: First, use wealth to obtain the blessings of Allah and strengthens faith in Allah, also cleansing oneself from greed. Second, responsibility towards family. Third, mandatory social obligations such as tax. Fourth, productive role in stimulating economic growth, improving efficiency and productivity, spend on research and development. Fifth, voluntary social responsibility to eradicate poverty and ignorance. Sixth, leadership role in protecting Islam, fight against injustice and exploitation, improve morality and market economy (Qardhawy, 1997; Mannan, 1986; Kahf, 1995).

Figure 1. Components of Islamic financial planning

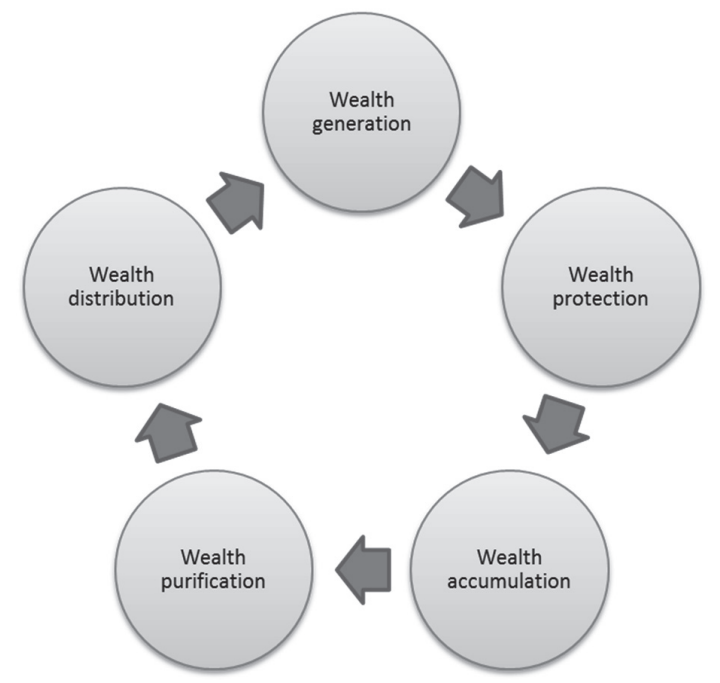

Source: Shafii et al (2013). 
Personal Finance in economic theory viewed as an application of the principles of finance, resource management, consumer education, and the sociology and psychology of decision making to the study of the ways that individuals, families, and households acquire, develop, and allocate monetary resources to meet their current and future financial needs. While personal financial planning is defined as the process of managing one's money to achieve personal economic satisfaction. Every person, family, or household has a unique financial position, and any financial activity, therefore, must also be carefully planned to meet specific needs and goals. The financial planning process is a logical, six-step procedure that can be adapted to any life situation. The process involves: determine the current financial situation, develop financial goals, identify alternative courses of action, evaluate alternatives, create and implement your financial action plan, review and revise the financial plan (Kapoor et al., 2012).

In Islam, the next verses are encouraging Muslims to plan for their life by working hard, spending moderately and saving for their future, that there are always uncertainties in life (Shafii et al., 2013). Al-Qur'an Surah Yusuf (12) verses 47-49 translated as follows:

(47) (Yusuf) said: "For seven years shall ye diligently sow as is your wont: and the harvests that ye reap, ye shall leave them in the ear,- except a little, of which ye shall eat. (48) "Then will come after that (period) seven dreadful (years), which will devour what ye shall have laid by in advance for them,- (all) except a little which ye shall have (specially) guarded. (49) "Then will come after that (period) a year in which the people will have abundant water, and in which they will press (wine and oil)."

And the next verse in Al-Qur'an Surah At-Takatsur (102) verse 8 translated as follows:

"Then, shall ye be questioned that Day about the joy (ye indulged in!)."

The verse is a sharia base that man will be held accountable (judged) later on the judgment day of indulgence that has been given to him in the world (Nizhan, 2011). Included among the indulgences given is in the form of a treasure. All Muslims, regardless of their economic status, is required to manage their wealth properly as they have responsibility for both their assets and liabilities (Shafii et al., 2013). The following hadith mention that humans will be liable for wealth: First, how was the wealth obtained; Second, how was it spent.

HR Al-Tirmizi No. 2417 translated as follows:

Both feet of a servant will not move on the judgment day until we asked about his age to what he spent, about his knowledge of what he practiced, about where he got his money from and where he spent them on, as well as about his body for what he used. 


\section{Method}

Qualitative approaches are incredibly diverse, complex and nuanced (Holloway and Todres, 2003), and thematic analysis should be seen as a foundational method for qualitative analysis. The approach chosen will take into account the purpose of the research, the role of the researcher, the data collected, method of data analysis, and how the results will be presented. Therefore to reach the objectives of research, this study consists of two steps in analyzing the phenomenon of consumerism through the perspective of personal finance. Firstly, analyzing the causes of consumerism and its impacts on personal finance. Secondly, proposing personal financial planning in Islamic wealth management concepts to create a solution for the problem of consumerism in personal finance.

This paper mainly focuses on Indonesia; therefore the research uses primary data sources, which consists of renowned ten informants of personal financial planning consultants, three key informants of Islamic Economics academicians in Indonesia, and ten kinds of the literature of Islamic Economics. The informants and critical informants are considered as experts in the field of personal financial planning and Islamic Economics in Indonesia.

Data collected are analyzed using thematic analysis method. Thematic analysis method has 6 phases in analyzing qualitative data. They are: First, familiarizing with data; Second, generating initial codes; Third, searching for themes; Fourth, reviewing themes; Fifth, defining and naming themes; Sixth, producing the report (Braun and Clarke, 2008).

\section{Result and Discussion The Root of Consumerism}

Most of our decades thoroughly with the sustainability discourse which incorporated the concepts of good life, wellbeing, and happiness as part of the economic development paradigm as a path toward societal welfare. It is not surprising that prosperity is also measured by the extent to which our society meets its consumption, which we unwittingly have built a consumerist society. Consumer society, in fact, is a complex system of technology, culture, institutions, markets, and dominant business models. It is driven by the ideology of neoliberalism and infinite growth. It has evolved through the sophisticated exploitation of the fundamental human quest for a meaningful life and wellbeing (Skidelsky and Skidelsky, 2012 as cited in Halina and Vergragt, 2015).

Consumerism in the society is caused by a series of relevant factors that are connected to each other. The increase of people with middle-level income creates demand for consumption. This higher demand encourages an increase in the supply 
of goods and services. Macroeconomics condition with international debts and agreements are also causing an increase in the supply of goods and services. Easy access to consumer credit then follows the vast availability of supply. Advertisements in mass media and messages in social media promote a consumptive lifestyle. In another hand, there is no sufficient personal financial education both formally and informally. These create individuals with low self-control for overconsumption who cannot differentiate between needs and wants. One more cause is because Muslims do not manage their finance by Islamic principles.

Figure 2. Factors Causing Consumerism Divided into Two Categories

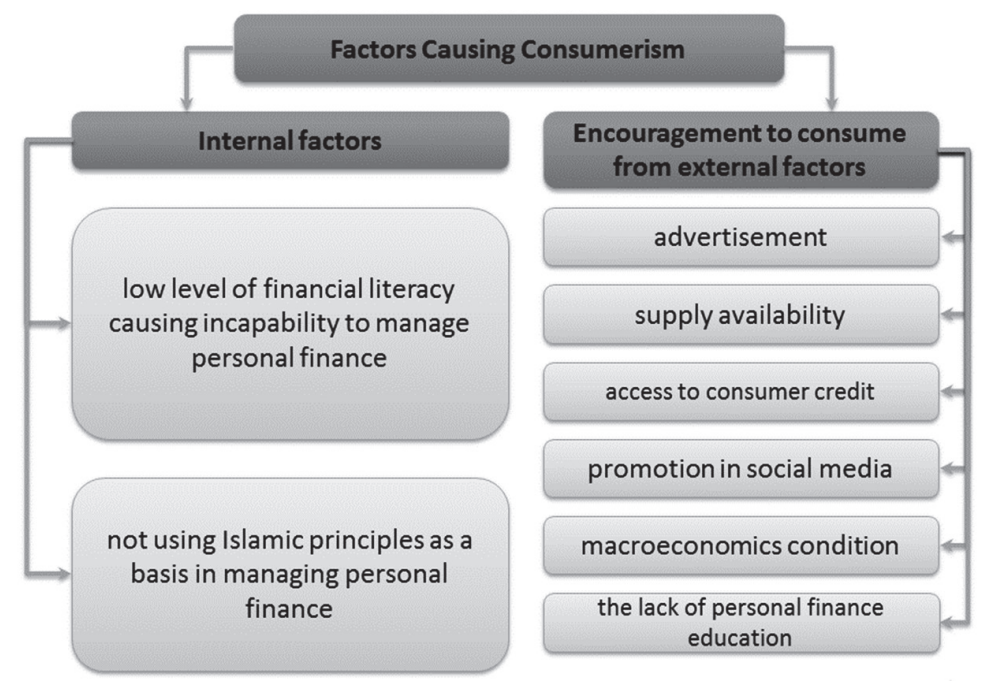

Factors mentioned above can be divided into two major categories: First, external factors; and; Second, internal factors. External factors consist of encouragement to consume in the form of income level rise, availability of supply, macroeconomic conditions, and easy access to consumer credit, advertisements, promotion in social media, and the lack of personal finance education. Internal factors that cause consumerism are the low level of financial literacy causing incapability to manage personal finance, and not using Islamic principles as a basis for managing personal finance. The themes of these causes will be described in the next part. (See Figure 2)

The lack of personal financial education both formally and informally causes low financial literacy in the society. One thing can prove the unavailability of sufficient personal finance education in formal school; personal finance is not a subject that can be found in the curriculum of elementary school until higher education such 
as high school and universities. While informal education for Muslims society in Indonesia, mainly centered in Masjids and Masjid-centered informal school, do not discuss much how to manage personal finance. Within the families, most parents never discussed personal finance with the children because it is considered a secret.

In the real world, everybody is exposed to sophisticated advertisements depicting happiness can be bought by consumptions. Unaware of this hidden message, society perceives that someone who can buy a lot of things is a successful person. Communication in social media also encourages consumption by promoting the consumptive lifestyle. The advances in technology help facilitate advertisements and social media communication on promoting the consumptive lifestyle.

Macroeconomics condition contributes to the raised consumption level in personal finance. Among the relevant factors are personal income level, policy on imported goods, distribution of consumer goods, the shift of economic base, and policy of consumer credit. Personal income level has risen in the last decade, and thus more money can be used for consumption. It is supported by the vast and widespread availability of consumer goods facilitated by the policy on imported goods into Indonesia and the better distribution of goods across Indonesia. That was also as a consequence of the shift from the agricultural-based economy into the industrial-based economy. And then, easy access to consumer credit allows the formerly unaffordable items turned into affordable items for more consumers.

The above external aspects altogether added by internal drive created individuals with low level of financial literacy. Low level of financial literacy is causing incapability to manage personal finance. Not being able to differentiate between needs and wants, and not having the right sense of financial priorities show the incapability. An added point of view is that consumerism in Muslims community happened because the Muslims do not practice Islamic teachings comprehensively. They do not manage their wealth according to Islamic principles. They also adopt a trending consumer lifestyle without considering if the new lifestyle is one that is encouraged by Islam or not (Basri, 2007).

\section{Negative Impacts of Consumerism}

Consumerism brings numerous negative impacts. The negative impacts affect both the society in general and the individuals' finance. Negative impacts of consumerism on individuals' finance reported are an imbalance, debt trap, no long-term financial goals, no productive and charity allocation. While taking in a broader range, consumerism has negative impacts on personal condition of Muslims in general and on society. Imbalance in personal finance is the condition where income statement and costs structure in a personal financial report is not 
compatible. Consumerism for some individuals could trigger the habit of spending more than income. The number of total consumption costs is bigger than the number of personal income. If such condition continues, one could fall into a debt trap. Debt trap defines the condition of dependence on debt for consumption. In severe cases of the debt trap, it could eventually scrape into existing personal assets for individuals who started with a high number of personal assets.

In personal finance that has corrupted with uncontrolled consumerism, income allocation is only concentrated on short-term consumption based on both needs and wants. Spending on wants is done without paying attention to long-term financial needs such as education and retirement preparation. Saving and investment goals for long-term financial needs cannot be achieved. Focusing on consumption also make people forgetting the need to allocate income for productive and charity purposes. The importance of allocating personal income for productive and charity purposes in Islam will be understood by understanding the further explanation in the next part.

Figure 3. Negative Impacts of Consumerism on Personal Finance

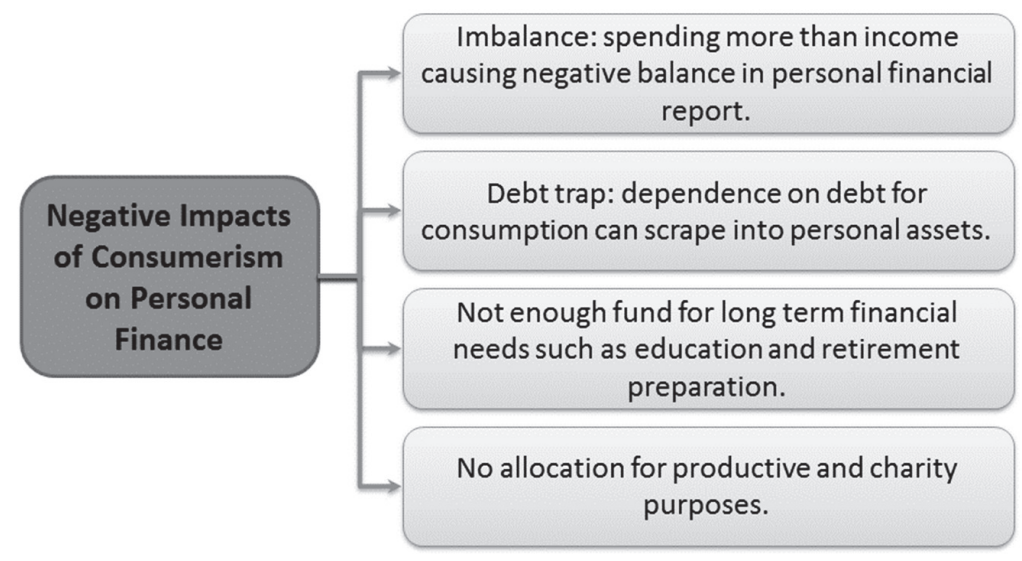

In Islamic perspective, negative impacts of consumerism on individuals and society cannot be separated because society is built from a group of individuals. These are the negative impacts: it is a tool for committing sins, brings concerns and serious problems to individuals and family, a waste of wealth, hindering from the remembrance of Allah, creating hatred and jealousy from the poor to the wealthy, boosting inflation. All of these problems causes mischief and destruction, corrupting worldly and religious matters, boosting wealth inequality, economics imbalance, resources scarcity, wealth distributed within forbidden sectors and distributed unevenly. For the summary it shows at Figure 3. 


\section{Bringing Wealth Back into Islamic Perspective}

Basically the problem of consumerism is Muslims do not practice Islamic teachings comprehensively, implied two important points that we must consider, ignorance and neglect. Therefore bringing back the concept of wealth and how to manage it Islamic teaching is really substantial matters. Fundamentally, the concept of wealth in Islam is described in four main themes of: wealth itself, rizqi, blessings, and standard of sufficiency. These concepts are specifically taken from the perspective of Islamic wealth management and Islamic view on work (Possumah, et. al, 2012). In Islam, wealth is translated from the word al-mal, which has meaning of lean, tend, and slant. By definition, wealth is something that has material values and can be owned, used, and kept or saved according to Islamic sharia law (Ismail, 2014). Main points of wealth in Islam are (Ismail, 2014): First, the absolute ownership of wealth is in Allah's hand; Second, wealth is a favor from Allah; Third, wealth is a main pillar of Dakwah; Fourth, wealth as a means to achieve al Falah. Allah is the absolute owner of all wealth, and while in the world human is being given wealth as a favor from Allah. This is a consequence of tauhid, one who claim Islam, as ones religion should believe this. And as a manager of Allah's wealth, human must manage wealth according to the rules set by the owner. One way to spend wealth is to facilitate Dakwah in order to achieve welfare and well being of human in this world and in the hereafter.

One absolute thing about rizqi is that it is predestined by Allah and cannot be affected by human's effort (Asy-Sya'rawi, 1993). Rizqi in Islam is defined as something that can be used and taken benefit and advantage by human infallibly, regardless both haram or halal and good or bad (Asy-Sya'rawi, 1993). The benefit refers to two forms: First, material benefit to be used to survive; Second, benefit of values to enrich life. In terms of wealth, there are two kinds of rizqi: positive and negative. Positive rizqi is the condition where one's income is always surplus. Negative rizqi is the condition where one's income is wasted on unimportant things and always minus. One main principle to follow in managing wealth is that it should be spent based on the right priority scale according to Islamic law so that it evokes more blessings, or berkah, from Allah (Asy-Sya’rawi, 1993).

Standards of sufficiency and wealth are measured by social custom and convention instead of by language or sharia law (Al-Asyaqar, 2006). Criteria for sufficiency are everything that perfectly meets the basic needs of human being and is able to alleviate human life into a decent level (Lam bin Ibrahim, 2005). While someone is said to be wealthy when one has more than one need. Worthy wealth for Muslims are the ones that meet these criteria: First, more than enough to meet basic needs of an individual and family; Second, can facilitate a comfortable life in a clean 
and nice environment; Third, able to fund education; Fourth, can grow business or facilitate effort of earning a living; Fifth, no need to worry about financial future; Sixth, can afford to be generous; Seventh, able to provide time for self-development; Eight, enough fund for the future of family and religion; Ninth, using wealth productively instead of wasting it, (10) able to provide time for cultural development.

\section{Personal Financial Planning as Eliminator}

In the effort of eliminating negative impacts of consumerism on personal finance, concepts of personal financial planning can contribute greatly (Aldridge, 1997). By planning personal finance, enables individuals and family to: prepare fund for short term and long term needs, make financial priorities, anticipate the risk of loss, differentiate needs and wants, consume only what is needed, escape from the lifestyle trap of excessive consumption, understand financial instruments as means to achieve financial goals, view wealth proportionally and aware of personal financial position. A well-managed wealth would benefit human life through promoting wealth distribution and equality, while a poorly managed wealth would results in inequality and misery. Mu'awiyah, an Islamic classic leader, said that management of wealth is half of the effort in earning livelihood (Syahatah, 1998). This has an even bigger effect if financial planning is practiced within family; it involves financial education to the children as early as possible and will create financially responsible adults.

In order to achieve a solution, personal income should be allocated for various aspects and should not be all spent on consumption. An exact number of maximum consumption cannot be set for every individual or family because personal finance is unique to each condition. One thing to be agreed upon is the main rule in personal financial planning, which is to allocate income based on the right priority scale. The percentage set by personal financial planning consultants as a maximum limit for consumption are ranged from $40 \%, 75 \%, 87,5 \%$, and $90 \%$ out of total personal income.

\section{Regulating Consumption behavior by Islamic Wealth Management (IWM) Approach}

To regulate the consumer behavior of human in managing the sufficiency of wealth, especially in personal finance, IWM has three principles that can be used as a foundation for consumption in personal finance. The three principles are: First, halal and good; Second, moderation; and; Third, balance. Muslims should only consume what Islamic sharia law allows; this is called halal. Principle of halal should not only be applied in consuming food, but also for every aspects of personal consumption. A share of personal income for consumption should only 
be allocated into halal things, and none can be allocated into forbidden or haram things. Consuming halal things is not done without limitation (Basri, 2007). There are certain rules and boundaries to follow, which are to consume thayyib things. Thayyib things are good, pure, and clean. By allocating personal income into consuming things that are allowed, good, pure, and clean, Muslims hope to achieve Allah's blessings in their lives.

Moderation means a condition between insufficient and excessive. Allocating a share of personal income for consumption should be done moderately, by avoiding both excessive spending and insufficient spending. Excessive spending is a lifestyle that corrupts soul, wealth, and society. Insufficient spending (miser) is a lifestyle that detains, freezes, and makes idle wealth (Lam bin Ibrahim, 2005). Balance in personal finance means that there is a match between the amount of income and the amount of spending (Syahatah, 1998). Personal spending should never exceed personal income. Providence in consumption will results in economic balance. Extensions to this principle are balance between: spending for personal needs and social charity, spending for short term needs and long term needs.

In Islamic wealth management insight, there are some applied concepts specifically can be used in an effort to eliminate negative impacts of consumerism on personal finance. The specific concepts are listed as follows: hierarchy of consumption, differentiate between needs and wants, modest lifestyle, prohibition of luxurious and redundant lifestyle, avoid debts, priorities in consumption and Maqashid sharia, zakat and Shadaqoh.

Hierarchy of consumption in Islamic wealth management explains the levels of consumption started from the lowest level of zero to the highest level of infinite (Basri, 2007). A consumption level equal zero is something that is neither encouraged nor allowed in Islam, because it could bring destruction to human life. An allowed level of consumption started from having to consume to be able to survive, this is fardhu' 'ain, a must for every human. Another allowed and encouraged level is consuming sufficiently, which is mubah and fardhu kifayah for Muslims. The allowed and encouraged level ends at the level of consuming a lot that is explained by the term sarof. Israf is consuming excessively and more than standard needs. All area of consuming excessively is not allowed in Islam and considered as a nonIslamic lifestyle.

In Islamic microeconomics, consumption closely related to concepts of needs (hajat), wants (raghbah), and lust or passion (shahwat). Needs is what human had to consume to be able to survive and to take care of their responsibilities. Wants refers to non-essential goods and services but are important for human living standard. Passion or lust is the human love for luxurious things and services (Mobley et.al, 
1995). Consumption for Muslims shouldn't be done without value but should be done with ibadah as a motive. Spending personal income for consumption based on needs and wants is allowed, while consumption based on passion or lust should be done cautiously (Basri, 2007).

Modest is a moderate and balance lifestyle. Modest is used to explain a spending habit that is neither spendthrift nor miserly, between tabdzir and bakhil. Tabdzir is using something not in its place, while bakhil is restraining from spending personal wealth. Islam promotes modest and unpretentious lifestyle as opposed to the extravagant, flamboyant, and arrogant lifestyle. With modest lifestyle, exploitation and waste of resources can be minimized (Basri, 2007).

Allah loves beautiful things, and an Islamic perspective on comfortability in life is cleanliness and tidiness. Luxury is not something that is absolutely prohibited in Islam, but it is allowed with a few rules. Firstly, luxury is only allowed for those who can afford it or in other word for wealthier people. Secondly, it should be completely free from the intention to show off wealth to other people. Displaying luxurious things with the intention to show off in the middle of poor community could bring social jealousy and in the end causes social damage. Thirdly, the luxury consumed should also be something that is needed, because spending for something useless is not allowed even if one can afford it.

Avoiding debt trap is one important part in an integral concept of Islamic wealth management. Taking debts over unimportant things are highly discouraged. Islam originally allows debts, but it is only a solution for when there is none other alternative other than taking debts. It is done with restriction of: First, every debt transaction should be noted and witnessed; Second, debtor should have an intention of paying back, borrowing without intention to pay back is not allowed.

Study of maqashid sharia or the objectives of Islamic law can be used as a priority scale in consumption (Ismail, 2014). Maqashid sharia consists of dharuriyah, hajjiyah, and tahsiniyyah. Dharuriyah is basic necessities in Islamic perspective; this includes preservation of faith, soul, wealth, mind, offspring, and honor. Hajjiyah is needs or requirements which aim at facilitating life or removing hardships in meeting the necessities. Tahsiniyyah is meant to compliment the fulfilment of necessities and needs. Priority scale in allocating personal income should starts from the fulfilment of obligation (fard al-'ayn), followed by allocation for encouraged activities (mandub), and allowed activities (mubah).

In essence, rizqi of a human goes only in three ways (Asy-Syàrawi, 1993): (1) what they eat will end up as a human waste, (2) what they use will end up as garbage, and (3) what they give to other people as charity will be long lasting forever until beyond the end of human time in this world. This is a concept that should be 
remembered by every Muslim. Zakat is something that must be paid by Muslims who has fulfilled the requirement in Islamic laws. For summary, the solution of Islamic wealth management can be seen in Figure 4.

Figure 4. Islamic Wealth Management as Solution for Consumerism

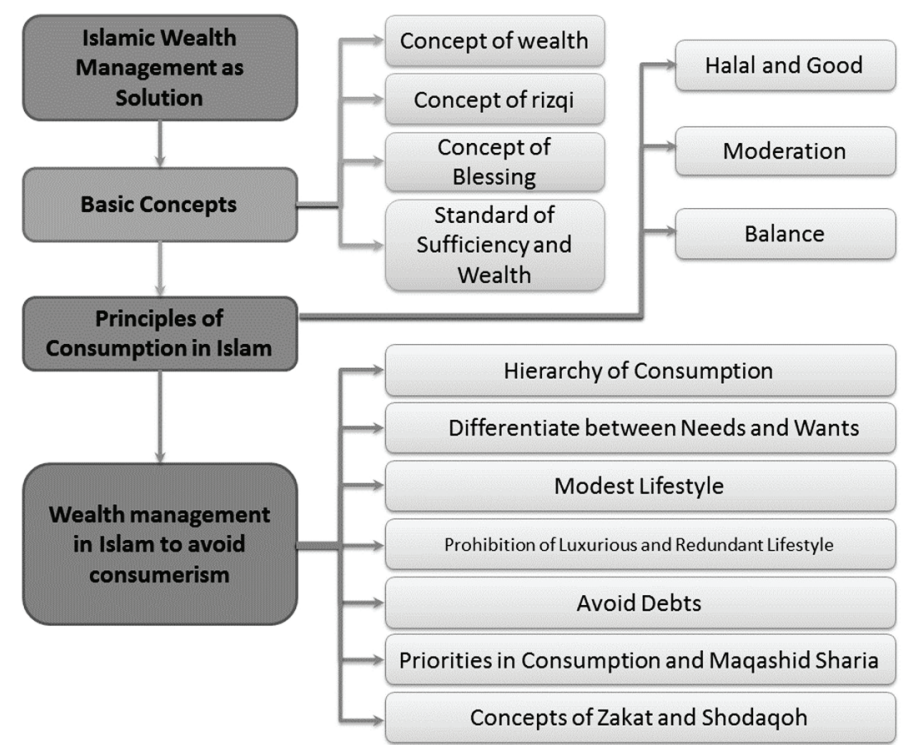

\section{Conclusions}

Consumerism that is caused by internal and external factors has negative impacts on the condition of personal finance. Islamic wealth management provided the solution for the problem of consumerism on personal finance through understanding fundamental concepts of Islamic wealth management, practicing financial planning, and using principles of consumption to avoid consumerism. IWM has three principles that can be used as a foundation for consumption in personal finance. The three principles are (1) halal and good, (2) moderation, and (3) balance. When these principles applied to regulate the consumer behavior of the human in managing the sufficiency of wealth, especially in personal finance, normatively we believe that consumerism issues would be reduced. But, since this study has a limitation of collecting data only from secondary sources, a conclusion taken from the descriptive qualitative discussion as above. Therefore for further study, researchers could do a case study of Islamic wealth management concepts used to counteract negative impacts of consumerism on personal finance. 


\section{References}

Al-Asyaqar, S. (2006). Manajemen Harta (Wealth Management). Depok: Bina Mitra Press.

Aldridge, A. (1997). Engaging with Promotional Culture: Organised Consumerism and the Personal Financial Services Industry. Sociology. Vol. 31 (3): 389-408. doi: https://doi.org/10.1177/0038038597031003002.

Asy Syảrawi, M. M. (1993). Rezeki (Ar Rizqu). Jakarta: Gema Insani Press.

Basri, I. A. (2007). Menguak Pemikiran Ekonomi Ulama Klasik (Revealing Economic Thought of Classical Scholars). Solo: Aqwam.

Basgöze, P., \& Tektas, Ö. Ö. (2012). Ethical Perceptions and Green Buying Behavior of Consumers: A Cross-national Exploratory Study. Journal of Economics and Behavioral Studies. Vol. 4(8): 477-488.

Bauman, Z. (2005). Work, Consumerism and The New Poor: $2^{\text {nd }}$ ed. England: Open University Press.

Braun, V., \& Clarke, V. (2008). Using Thematic Analysis in Psychology. Qualitative Research in Psychology. Vol. 3(2): 77-101. doi: https://doi. org/10.1191/1478088706qp063oa.

Dowd, D. (2009). Inequality and The Global Economic Crisis. USA: Pluto Press.

Essoussi, L. H., \& Linton, J. D. (2010). New or Recycled Products: How Much are Consumers willing to pay? Journal of Consumer Marketing. Vol. 27(5): 458-468. doi: http://doi.org/10.1108/07363761011063358

Fligstein, N., \& Mc Adam, D. (2012). A Theory of Fields. New York: Oxford University Press.

Halina, S. B., \& Philip J. Vergragt (2015). From Consumerism to Wellbeing: Toward a Cultural Transition? Journal of Cleaner Production. Vol. 132: 308-317.

Heryanto, J. (2004). Pergeseran Nilai dan Konsumerisme di Tengah Krisis Ekonomi di Indonesia (Shifting Values and Consumerism Amid The Economic Crisis in Indonesia). Nirmana. Vol. 6 (1): 52-62.

Indrajit, R. E., \& Djokopranoto, R. (2011). Wealth Management untuk Penyelenggaraan Perguruan Tinggi (Wealth Management for University Management). Yogyakarta: CV Andi Offset.

Ismail, N. (2014). Maqashid Syariah dalam Ekonomi Islam (Maqashid Shariah in Islamic Economics. Yogyakarta: Smart WR.

Kahf, M. (1995), Ekonomi Islam: Telaah Analitik terhadap Fungsi dan Sistem Ekonomi Islam (Islamic Economics: Analytical Review of The Function and System of Islamic Economics). Yogyakarta: Pustaka Pelajar. 
Kapoor, J. R., Dlabay, L. R., \& Hughes, R. J. (2012). Personal Finance. Tenth Edition. New York: The McGraw-Hill Companies, Inc.

Kasser, T., \& Kanner, A. D. (Eds). (2004). Psychology and Consumer Culture: The Struggle for a Good Life in a Materialistic World. Washington, DC: American Psychological Association.

Mannan, M. A. (1986). Islamic Economics; Theory and Practice (Foundation of Islamic Economics). England: Holder and Stoughton Ltd

Manurung, A. H. (2008). Wealth Management: Menuju Kebebasan Finansial (Wealth Management: To Financial Freedom). Jakarta: Kompas.

Mobley, A. S., Painter, T. S., Untch, E. M., \& Unnava, H. R. (1995). Consumer Evaluation of Recycled Products. Psychology and Marketing. Vol. 12(3): 165-176.

O’Neill, B., Bristow, B., \& Brennan, P. (2000). Changing Financial Behavior: Implications for Family and Consumer Sciences Professionals. Journal of Family and Consumer Sciences. Vol. 99(4): 43-48.

Possumah, B. T., Baharuddin, G., \& Ismail, A. G. (2012). Religious Based Economy: Reflection on Economic Development Outcomes in Islam. Proceding Paper in International Conference on Social Sciences \& Humanities (ICOSH), FSSK UKM, 12-13 Dec 2012 Malaysia.

Qardhawi, Y. (1997), Norma dan Etika Ekonomi Islam (Norms and Ethics in Islamic Economics). Jakarta: Gema Insani Press.

Shafii, Z., Zarinah, M. Y., \& Shahizan, Md. N. (2013). Islamic Financial Planning and Wealth Management. Kuala Lumpur, Malaysia: IBFIM.

Solomon, M. R. (2013). Consumer Behavior: Buying, Having, and Being (Tenth Edition). Essex: Pearson Education Limited.

Stearns, P. N. (2001). Consumerism in World History: The Global Transformation of Desire. London: Routledge.

Swagler, R. (2005). Evolution and Applications of the Term Consumerism: Theme and Variations. Journal of Consumer Affairs. Vol. 28 (2): 347-360.

Syahatah, H. (1998). Ekonomi Rumah Tangga Muslim (The Economy of Muslim Household). Jakarta: Gema Insani Press.

Taylor, D. S., \& Overbey, G. (1999). Financial Practices and Expectations of Student and Non-student Consumers. Journal of Family and Consumer Sciences. Vol. 91(4): 39-42.

Wrenn, B., Loudon, D., \& Bitta, A. D. (2013). Consumer Behavior: Putting Theory into Practice (Fifth Edition). New Jersey: Textbook Media Press. 